Rev. Téc. Ing. Univ. Zulia. Vol. 42, No. 3, 2019, 143-151

\title{
Antibacterial property of cancrinite-type zeolites exchanged with silver and copper cations
}

\author{
Freddy Ocanto ${ }^{1 *}$, Carlos F Linares ${ }^{1}$, Edith Figueredo ${ }^{1,2,}$ Caribay Urbina de Navarro $^{3}$ \\ ${ }^{1}$ Unidad de Síntesis de Materiales y Metales de Transición, Departamento de Química, Facultad Experimental \\ de Ciencias y Tecnología, Universidad de Carabobo, Apartado 3336, Valencia 2005, Venezuela. \\ ${ }^{2}$ Laboratorio de Calidad Ambiental, Escuela de Ingeniería Civil, Facultad de Ingeniería, Universidad de \\ Carabobo, Apartado Postal 3336, Valencia 2005, Venezuela. \\ ${ }^{3}$ Centro de Microscopía Electrónica Dr. Mitsuo Ogura, Escuela de Biología, Facultad de Ciencias, Universidad \\ Central de Venezuela, Apartado 20513, Caracas 1020-A, Venezuela. \\ *Autor de correspondencia: ocantow@gmail.com \\ https://doi.org/10.22209/rt.v42n3a06 \\ Recepción: 22/08/2018 | Aceptación: 05/06/2019 | Publicación: 01/09/2019
}

\begin{abstract}
$\mathrm{Ag}^{+}, \mathrm{Cu}^{2+}$ or $\mathrm{Ag}^{+}-\mathrm{Cu}^{2+}$ ion-exchanged nitrate-sodium cancrinite-type zeolites were tested as bactericidal agents against Escherichia coli (E. coli) and Pseudomonas aeruginosa (P. aeruginosa). Nitrated-sodium cancrinite was synthesized using solutions of $\mathrm{NaOH}$ and $\mathrm{NaNO}_{3}$, and using zeolite $\mathrm{X}$ as $\mathrm{Al}$ and Si sources under hydrothermal conditions at $80 \stackrel{\circ}{\circ} \mathrm{C}$ and autogenous pressure during $40 \mathrm{~h}$. Solids were characterized by powder X-ray diffraction (XRD), Fourier transformed infrared spectroscopy (FT-IR), scanning electron microscopy (SEM) and chemical analysis. Then, different masses of these ionexchanged zeolites were mixed with the microorganisms. Results showed that E. coli was more sensitive than P. aeruginosa, and $2.5 \mathrm{mg}$ of $\mathrm{Ag}^{+}$or $\mathrm{Cu}^{2+}-\mathrm{Ag}^{+}$cancrinites were enough to inhibit the $E$. coli growth, while for P. aeruginosa larger amounts of $\mathrm{Ag}^{+}(5 \mathrm{mg})$ and $\mathrm{Ag}^{+}-\mathrm{Cu}^{2+}(20 \mathrm{mg})$ of the cancrinites were necessary. Cu-zeolites did not show bactericidal activity. Different treatments times between these microorganisms and the modified zeolites were also investigated. A 20 min treatment was enough to inhibit totally the bacterial growth. As a reference system zeolite A exchanged with these metals was used.
\end{abstract}

Keywords: nitrate cancrinite, silver, antibacterial, E. coli, P. aeruginosa.

\section{Propiedad antibacteriana de zeolitas tipo cancrinita intercambiadas con iones plata y cobre}

\section{Resumen}

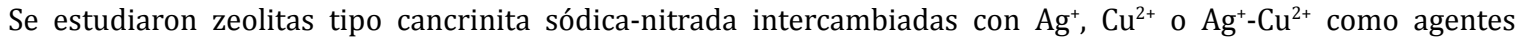
bactericidas contra Escherichia coli (E. coli) y Pseudomonas aeruginosa ( $P$. aeruginosa). La zeolita sódica-nitrada fue sintetizada utilizando soluciones de $\mathrm{NaOH}, \mathrm{NaNO}_{3}$, y zeolita X como fuente de $\mathrm{Al}$ y Si en condiciones hidrotérmica, $80{ }^{\circ} \mathrm{C}$, presión autógena durante $40 \mathrm{~h}$. Los sólidos fueron caracterizados por difracción de rayos X de polvo (DRX), espectroscopia de infrarrojo con transformada de Fourier (FT-IR), microscopía electrónica de barrido (MEB) y análisis químico. Diferentes masas de zeolitas intercambiadas fueron puestas en contacto con estos microorganismos. Los resultados mostraron que la $E$. coli es más sensible que la $P$. aeruginosa y $2,5 \mathrm{mg}$ de la cancrinita intercambiada con $\mathrm{Ag}^{+}$o $\mathrm{Ag}^{+}-\mathrm{Cu}^{2+}$ fue suficiente para controlar la población completa del microorganismo. Sin embargo para controlar la población de la P. aeruginosa, se necesitó una cantidad mayor de la cancrinita modificada $\mathrm{Ag}^{+}(5 \mathrm{mg})$ y $\mathrm{Ag}^{+}-\mathrm{Cu}^{2+}(20 \mathrm{mg})$. Las zeolitas intercambiadas con cobre no presentaron actividad bactericida. Se estudió el efecto de diferentes tiempos de contacto entre estos microorganismos y las zeolitas modificadas; encontrándose que a los 20 minutos un efec to bactericida. Zeolitas A intercambiadas con estos mismos metales fueron usadas como referencia.

Palabras claves: nitrato-cancrinita, plata, antibacterial, E. coli, P. aeruginosa. 


\section{Introduction}

Cancrinites are special zeolites conformed by small cages ( $\varepsilon$-cages) distributed in a hexagonal structure and a big channel of 12 rings along the direction of the hexagonal $c$ axis of the structure, forming one-dimensional rectilineous channels along this axis. Access to these channels occurs through windows formed by 12 member rings [1]. Usually, anionic species such as: nitrate, sulfate, oxalate, thiosulfate, etc., are found inside of the big channel of the structure compensating the positive charge generated by sodium cations placed in the $\varepsilon$-cages [2-4]. Due to the blocking of pores by anions inside of the cancrinite's structure, few pharmaceutical or industrial applications have been reported in the literature [5-7].

Sodium-zeolite, per se, do not have bactericide effect but several ion-exchanged cations in its structure are active as bactericidal agents. Due to the fact that cancrinite-type zeolites show a Si/Al ratio close to 1, they could be good candidates to be exchanged with cations such as $\mathrm{Ag}^{+}$ or $\mathrm{Cu}^{2+}$ which are recognized antibacterial agents.

Likewise, Rivera-Garza [8] studied a mexican natural zeolite (clinoptilolite-heulandite) exchanged with different $\mathrm{Ag}^{+}$proportions. These modified zeolites were tested as antibacterial agents in contaminated waters with Escherichia coli and Streptococcus faecalis. Results showed that both bacteria could be eliminated at the highest used silver amount after $2 \mathrm{~h}$ of contact time.

Milán [9] modified natural clinoptilolites with different heavy metals $\left(\mathrm{Ni}^{2+}, \mathrm{Zn}^{2+}, \mathrm{Fe}^{3+}\right.$ and $\left.\mathrm{Cu}^{2+}\right)$. These zeolites were tested on pure cultures of $E$. coli and $P$. aeruginosa. Results established a decreasing order of the bactericidal capacity being $\mathrm{Cu}^{2+}>\mathrm{Fe}^{3+}>\mathrm{Zn}^{2+}>\mathrm{N}^{\mathrm{i} 2+}$

Otherwise, Inoue [10] found that silver-loaded zeolites had a strong bactericidal activity against $E$. coli. Dissolved oxygen in the culture medium was an essential factor for the occurrence of the bactericidal activity because it was only observed under aerated condition.

Other zeolites and cations have also been used in medical applications [11, 12], environmental management in shrimp aquaculture [13] and bactericidal agents for water disinfection [14, 15]; however, cancrinite-type zeolites have been few mentioned for this last purposes $[16,17]$, basically because they have a low ion-exchange capacity. Their low ion-exchange capacity is due to the blocking of pores by anions inside of the main channels. However, this can be profitable taking into account that several cations, such as silver, can act as bactericide even at low concentrations. Therefore, it could reduce the reactant amount and avoid environmental troubles.

Although zeolites act as metal carriers they do not show per se antibacterial effects. The metallic load depends on the $\mathrm{Si} / \mathrm{Al}$ ratio: zeolites $\mathrm{A}$ and $\mathrm{X}$ have a high exchanged capacity because their $\mathrm{Si} / \mathrm{Al}$ ratio is closed to 1 ; cancrinite-type zeolites have a $\mathrm{Si} / \mathrm{Al}$ ratio close to 1 also, but they have a low exchanged capacity, this could be interesting because these antibacterial metals act at low concentrations saving costs and avoiding damages to the environment.

The aim of this paper was to modify cancrinitetype zeolites with silver, copper, and a silver-copper mixture and then test them as possible antibacterial agents against E. coli and $P$. aeruginosa. Likewise, an exchanged zeolite A with the same cations was also used as reference. Antibacterial properties of these solids depend on the $\mathrm{Si} /$ $\mathrm{Al}$ ratio which is the same for both zeolites.

\section{Experimental Section}

\section{Synthesis of sodium-nitrate cancrinite}

A nitrate cancrinite-type zeolite was synthesized according to the previously reported procedure [18]: 7.5 $\mathrm{g} \mathrm{NaNO}_{3}$ were dissolved into $50 \mathrm{~mL}$ of distilled water in a teflon reactor. Then, $10 \mathrm{~g} \mathrm{NaOH}$ were added and dissolved and finally $5 \mathrm{~g}$ zeolite $\mathrm{X}$ were also added to this solution forming a slurry. This reactor was sealed and put in a convection oven at $80{ }^{\circ} \mathrm{C}$ for $110 \mathrm{~h}$. Samples were filtered and washed with enough distilled water until a $\mathrm{pH}$ near 7.

\section{Ion-exchange procedure}

The synthesized nitrated-sodium cancrinite was ion-exchanged with silver, copper and a mixture of silvercopper cations. $15 \mathrm{~mL}$ of solution $(0.02 \mathrm{M})$ of $\mathrm{Ag}^{+}, \mathrm{Cu}^{2+}$ or and $\mathrm{Ag}^{+}-\mathrm{Cu}^{2+}$ mixture were added to $5 \mathrm{~g}$ of sodium-nitrate cancrinite forming a slurry. This slurry was agitated at $80{ }^{\circ} \mathrm{C}$ for $24 \mathrm{~h}$ in nitrogen atmosphere in the absence of light. The slurries were filtered off and supernatants were discarded. The filtered solids were kept for a new ionexchange. This procedure was repeated three times. After that, solids were washed up with abundant distilled water, filtered and dried for $110 \mathrm{~h}$ at $80{ }^{\circ} \mathrm{C}$.

\section{Characterization of modified cancrinites}

Ion-exchanged cancrinites with $\mathrm{Ag}^{+}, \mathrm{Cu}^{2+}$ and a $\mathrm{Ag}^{+}-\mathrm{Cu}^{2+}$ mixture were characterized by powder-X-ray diffraction (XRD), Fourier transformed infrared spectroscopy (FT-IR), chemical analysis and scanning electron microscopy (SEM).

XRD analyses were carried out by using a Siemens 5000 difractometer with a $\mathrm{CuK} \alpha$ radiation $(1.542$ $\AA$ ) for crystalline phase detection between 5 and $50^{\circ}$ ( $(2 \theta)$. The presence of functional groups and evaluation of solids purity were achieved by FTIR; spectra were recorded in a Perkin-Elmer 283 spectrometer in the 4000-400 $\mathrm{cm}^{-1}$ range. Samples were prepared by mixing the solids with $\mathrm{KBr}$ to form a thin pastille. The morphology of the products was observed on a Hitachi FEG-4500 scanning 
electron microscope (SEM) with $10 \mathrm{KeV}$ of acceleration. Samples were dispersed over a conductive surface and covered with a thin gold film.

\section{Assay of bactericidal activity}

E. coli and P. aeruginosa were used to assess the bactericidal activity of $\mathrm{Ag}^{+}, \mathrm{Cu}^{2+}$ and $\mathrm{Ag}^{+}-\mathrm{Cu}^{2+}$ modified cancrinites and zeolites A. These bacteria were collected from the Department of Microbiology (University of Carabobo). Brain-heart infusion was used as an aerobic growing medium for both microorganisms at $35^{\circ} \mathrm{C}$. Once microorganisms reached the exponential growing phase of cultures (after $18 \mathrm{~h}$ ), an aliquot of this suspension was diluted in a Mueller-Hinton culture medium to get approximately $1.5 \times 10^{8}$ units of colonies per plate (CFU). Then, $0.001 \mathrm{~mL}$ from this suspension was inoculated in $9.999 \mathrm{~mL}$ of Mueller-Hinton culture medium to get a $1 \times 10^{-4}$ dilution factor $\left(1.5 \times 10^{6} \mathrm{CFU}\right)$. In order to determine the CFU, $100 \mu \mathrm{L}$ from this medium were spread on a Mueller-Hinton agar plate and incubated at $35{ }^{\circ} \mathrm{C}$ for $24 \mathrm{~h}$ [19].

\section{Influence of zeolite mass}

Among 2.5 and $125 \mathrm{mg}$ of modified zeolites were mixed with $2 \mathrm{~mL}$ from a $10^{-4}$ diluted solution containing $E$. coli or $P$. aeruginosa. Samples were horizontally agitated for $6 \mathrm{~h}$ and then, slurries were kept in static condition for $24 \mathrm{~h}$. After that, an aliquot of $100 \mu \mathrm{L}$, was spread on a Mueller-Hinton agar plate and incubated at $35^{\circ} \mathrm{C}$ for $24 \mathrm{~h}$. Finally, the CFU was determined after contact with modified zeolites.

\section{Influence of contact time}

To study the contact time among modified zeolites and the microorganisms 5 and $20 \mathrm{mg}$ of modified zeolites were mixed with $2 \mathrm{~mL}$ of a $10^{-4}$ diluted solution containing E. coli or P. aeruginosa.

Samples were horizontally agitated during different contact times (14-1440 min), and aliquots of 100 $\mu \mathrm{L}$ were spread on a Mueller-Hinton agar plate and incubated at $35^{\circ} \mathrm{C}$ for $24 \mathrm{~h}$. Finally, the CFU was determined for each contact time.

\section{Results and discussion}

\section{Characterization of sodium-nitrate cancrinite}

XRD analysis (Fig 1) showed reflections attributed to the nitrated-cancrinite zeolite that were consistent with the P63 spatial group [20]. This diffraction pattern shows intense peaks corresponding to (110), (101), (210), (300), (211), (400), (311), (102) and (330) planes which are representatives of the nitrated-cancrinite zeo- lites (PDF 46-1332) [21, 22]. Other phases such as sodalite were not present in the synthesized sample.

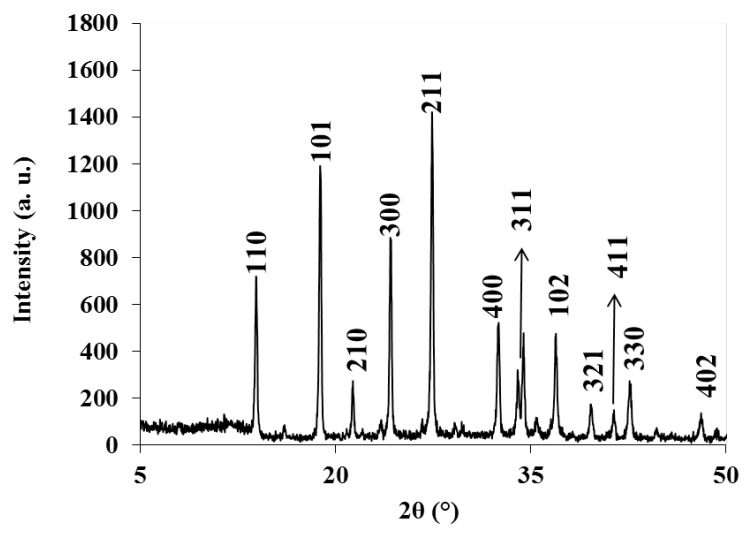

Figure 1. XRD pattern of nitrate-sodium cancrinitetype zeolite.

Fig. 2 shows the FTIR spectrum of the synthesized cancrinite-type zeolite. A series of characteristic bands could be identified [23, 24]: A band between 3500 and $3400 \mathrm{~cm}^{-1}$ corresponds to $\mathrm{OH}^{-}$groups from water molecules entrapped inside of the framework. While the band at $1639 \mathrm{~cm}^{-1}$ corresponds to water molecules inside of the framework.

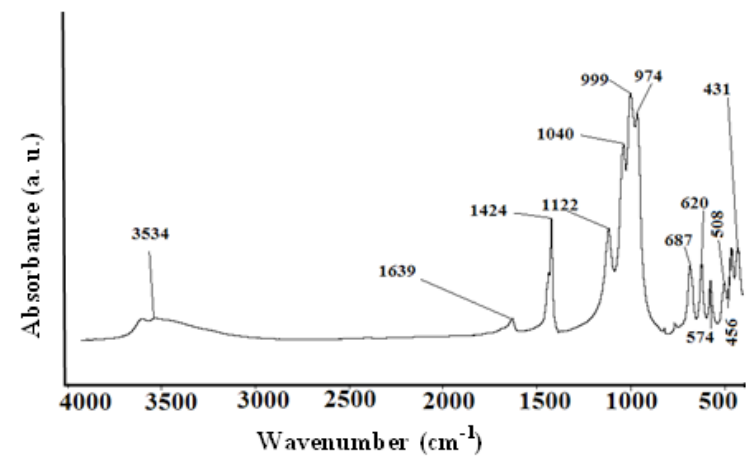

Figure 2. FT-IR spectrum of sodium-nitrate cancrinitetype zeolite.

A band at $1424 \mathrm{~cm}^{-1}$ was assigned to occluded nitrate anions as counter-anion in the internal cavities of the cancrinite zeolite. Bands in the region between 1122 and $974 \mathrm{~cm}^{-1}$ have been assigned to Si-0-Al asymmetric stretch vibrations of framework species. Three bands between 687 and $574 \mathrm{~cm}^{-1}$, called "cancrinite fingerprint" correspond to $\mathrm{Si}-\mathrm{O}-\mathrm{Al}$ symmetric stretch vibration bonds.

SEM analysis of the synthesized zeolite showed the presence of small hexagonal prismatic crystallites $(\sim 2 \mu \mathrm{m})$ of cancrinite zeolite (Fig. 3). These prismatic crystallites correspond to the cancrinite zeolite in agreement with Barnes [25]. 


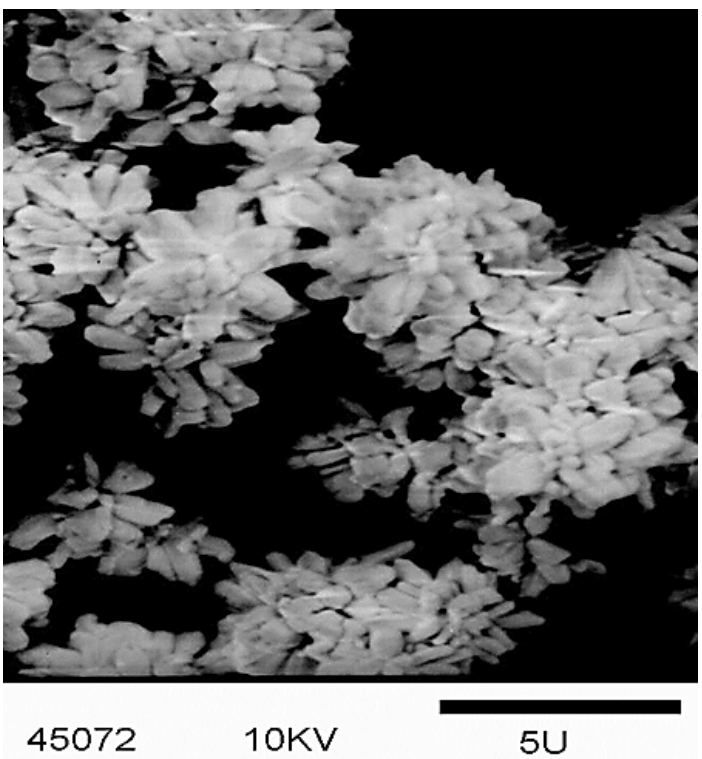

Figure 3. SEM of nitrate-sodium cancrinite type zeolite. Typical hexagonal crystals can be observed.

The $\mathrm{Si} / \mathrm{Al}$ ratio and formula of zeolites were determined by chemical analyses (Table 1 ). A Si/Al ratio $\approx$ 1 was obtained for both zeolites (cancrinite and zeolite A) which agree the revised literature [1].

This $\mathrm{Si} / \mathrm{Al}$ ratio was higher for the cancrinite zeolite than for the zeolite A. Experimental errors could be associated to these results. $\mathrm{A}$ similar $\mathrm{Ag}^{+}$and $\mathrm{Cu}^{2+}$ ionexchange amount was obtained for both zeolites. These results allowed a better comparison for these solids when they were used as antibacterial materials. The amount of exchanged $\mathrm{Ag}$ was superior to that of $\mathrm{Cu}$. These results are associated to the cation oxidation state. For each $\mathrm{Al}^{+}$ion from the Al-O-Si zeolite framework as possible to exchange one $\mathrm{Ag}^{+}$cation while two $\mathrm{Al}^{3+}$ were replaced for one $\mathrm{Cu}^{2+}$ ions in order to get the neutrality of the framework. Likewise, the metal ion-exchanged percentage $\mathrm{CAg}^{+}$or $\mathrm{Cu}^{2+}$ ) was very low. This result is due to the blocking of the pores in the cancrinite zeolite and the small pore size of the zeolite A structure as was previously mentioned [1].

\section{Influence of zeolite mass on the bacterial strains.}

\section{Escherichia coli}

Tables 2 and 3, shows the CFU of E. coli and P. aeruginosa determined on Mueller-Hinton agar plates before and after contact with different amounts of modified cancrinite zeolite or zeolite A. Results showed that those ion-exchanged zeolites with $\mathrm{Ag}^{+}$or $\mathrm{Ag}^{+}-\mathrm{Cu}^{2+}$ were more effective than those exchanged with $\mathrm{Cu}^{2+} .2 .5$ $\mathrm{mg}$ of these modified $\mathrm{Ag}^{+}$zeolites were enough to kill the whole bacteria population after $24 \mathrm{~h}$ of contact (Fig $4 \mathrm{a})$; while $50 \mathrm{mg}$ or more $\left(125 \mathrm{mg}\right.$ ) of $\mathrm{Cu}^{2+}$ modified zeolites were not able to control the proliferation of $E$. coli. It is probably that, at the assayed concentrations, the presence of $\mathrm{Cu}^{2+}$ cations does not have effect against $E$. coli population (Fig 4b). $\mathrm{Ag}^{+}$and $\mathrm{Cu}^{2+}$ cations have been reported as antibacterial materials $[8,9]$

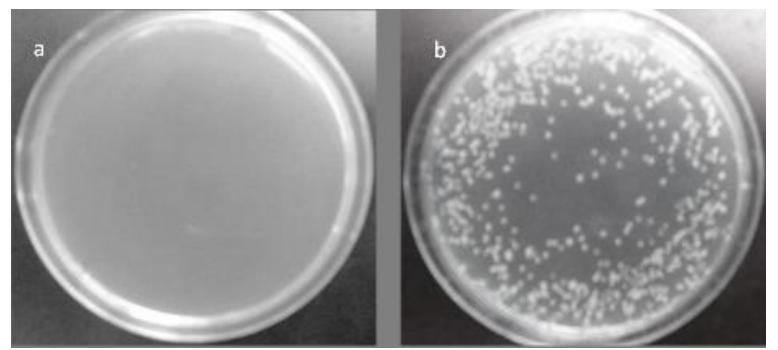

Figure 4. a) Bacterial growth on the agar plates containing $2.5 \mathrm{mg}$ of $\mathrm{Ag}$ zeolites, after $24 \mathrm{~h}$ incubation b) 50 $\mathrm{mg}$ of $\mathrm{Cu}^{2+}$ modified zeolites, after $24 \mathrm{~h}$ incubation.

However, several microorganisms show an increasing tolerance to copper, which is induced by resistance mechanisms, where copper resistant species appear [9]; moreover, low $\mathrm{Cu}^{2+}$ concentrations in the culture medium are also necessary as a micronutrient for bacteria [19]

According to our results, $\mathrm{Cu}^{2+}$ cations, from $\mathrm{Cu}-$ loaded zeolites, do not have effect against $E$. coli or, on the contrary, helps the vitality of this organism. Likewise, $\mathrm{Ag}^{+}$ cations were very effective against this organism even in presence of $\mathrm{Cu}^{2+}$ cations which, according to our results,

Table 1. Chemical analysis of the exchanged zeolites, chemical formula and exchange percentage.

\begin{tabular}{ccccc}
\hline Solids & Empirical formula & $\mathbf{\% A g}(\mathbf{p} / \mathbf{p})$ & $\mathbf{\%} \mathbf{C u}(\mathbf{p} / \mathbf{p})$ & $\mathbf{S i} / \mathbf{A l}$ \\
\hline $\mathrm{ZA}-\mathrm{Ag} / \mathrm{Cu}$ & $\mathrm{Na}_{91.06} \mathrm{Ag}_{2.21} \mathrm{Cu}_{0.73} \mathrm{Al}_{94.72} \mathrm{Si}_{97.28} \mathrm{O}_{384}$ & $1.3 \pm 0.1$ & $0.57 \pm 0.06$ & 1.03 \\
$\mathrm{ZA}-\mathrm{Cu}$ & $\mathrm{Na}_{92.08} \mathrm{Cu}_{0.97} \mathrm{Al}_{94.02} \mathrm{Si}_{97.80} \mathrm{O}_{384}$ & & $0.69 \pm 0.02$ & 1.04 \\
$\mathrm{ZA}-\mathrm{Ag}$ & $\mathrm{Na}_{92.73} \mathrm{Ag}_{2.07} \mathrm{Al}_{94.80} \mathrm{Si}_{97.80} \mathrm{O}_{384}$ & $1.3 \pm 0.1$ & & 1.03 \\
$\mathrm{Can}-\mathrm{Ag}$ & $\mathrm{Na}_{7.57} \mathrm{Ag}_{0.09} \mathrm{Al}_{5.66} \mathrm{Si}_{6.34}{ }_{24}\left(\mathrm{NO}_{3}\right)_{2}$ & $1.5 \pm 0.2$ & & 1.12 \\
$\mathrm{Can}-\mathrm{Ag} / \mathrm{Cu}$ & $\mathrm{Na}_{7.30} \mathrm{Ag}_{0.16} \mathrm{Cu}_{0.07} \mathrm{Al}_{5.60} \mathrm{Si}_{6.40} \mathrm{O}_{24}\left(\mathrm{NO}_{3}\right)_{2}$ & $1.6 \pm 0.1$ & $0.74 \pm 0.07$ & 1.14 \\
$\mathrm{Can}-\mathrm{Cu}$ & $\mathrm{Na}_{7.44} \mathrm{Cu}_{0.07} \mathrm{Al}_{5.58} \mathrm{Si}_{6.42} \mathrm{O}_{24}\left(\mathrm{NO}_{3}\right)_{2}$ & & $0.83 \pm 0.06$ & 1.15 \\
\hline
\end{tabular}

ZA: zeolite A. Can: cancrinite 
Table 2. CFU of E. coli determined on Mueller-Hinton agar plates before and after contact with different amounts of modified cancrinite zeolite or zeolite A.

$\begin{array}{cccc}\begin{array}{c}\text { Modified } \\ \text { zeolite }\end{array} & \begin{array}{c}\text { CFU } \\ \text { initial }\end{array} & \begin{array}{c}\text { Zeolite } \\ (\mathbf{m g})\end{array} & \begin{array}{c}\mathbf{N}^{\mathbf{0}} \mathbf{U F C} \\ (\mathbf{2 4} \mathbf{h})\end{array} \\ \text { Can-Ag } & 77 & 2.5 & 0 \\ & 77 & 5.0 & 0 \\ & 77 & 10.0 & 0 \\ \text { Can-Ag/Cu } & 19 & 2.5 & 0 \\ & 19 & 5.0 & 0 \\ & 19 & 10.0 & 0 \\ \text { Can-Cu } & 64 & 50.0 & \mathrm{U} \\ & 64 & 75.0 & \mathrm{U} \\ & 64 & 100.0 & \mathrm{U} \\ \mathrm{A}-\mathrm{Ag} & 64 & 125.0 & \mathrm{U} \\ & 106 & 2.5 & 0 \\ & 106 & 5.0 & 0 \\ \mathrm{~A}-\mathrm{Ag} / \mathrm{Cu} & 106 & 10.0 & 0 \\ & 48 & 2.5 & 0 \\ & 48 & 5.0 & 0 \\ & 46 & 10.0 & 0 \\ & 47 & 50.0 & \mathrm{U} \\ & 47 & 75.0 & \mathrm{U} \\ & 47 & 100.0 & \mathrm{U} \\ & 47 & 125.0 & \mathrm{U} \\ & & & \end{array}$

U: uncountable

could be considered as essential microelements. $\mathrm{Ag}^{+}$ ions can polarize thiol, nitrogen and oxygen groups from proteins producing the precipitation and irreversible inhibition of enzymes and others important proteins. The deactivation of these enzymes produces the death of these bacteria $[26,27]$. On the other hand, $\mathrm{Cu}$ is a bacterial nutrient, required as a cofactor by enzymes that catalyse electron transfer processes, for instance in aerobic and anaerobic respiration. To date, the inward flow of this metal ion as a nutrient and its insertion into target cuproenzymes has been reported [28]. Without these transition metal cations, a sophisticated cellular biochemistry is not possible. As a consequence, $\mathrm{Cu}^{2+}$ has to be imported into the bacterial cytoplasm [29].

The metallic concentration is an important factor when a bactericide should be evaluated due to its cost and environmental impact. The Ag content in zeolites such as clinoptilolites, A and X is relatively high (16.6 and 31.4\% $\mathrm{w} / \mathrm{w}$ respectively) $[8,30]$ in comparison to cancrinites $(1.5 \% \mathrm{w} / \mathrm{w})$. This represents an important saving of Ag and is ecofriendly due to the Ag content must be monitored in water bodies according to Venezuelan normative [31].
On the other hand, no difference was observed in the antibacterial activity between modified cancrinitetype zeolite and zeolite A. Antibacterial properties of these solids depend on the $\mathrm{Si} / \mathrm{Al}$ ratio which is the same for both zeolites.

\section{Pseudomonas aeruginosa}

Antibacterial assays were also carried out using $P$. aeruginosa. This microorganism is frequently responsible of microbial contaminations in hospitals. Table 3 reports results using different amounts of $\mathrm{Ag}^{+}$ or $\mathrm{Ag}^{+}-\mathrm{Cu} 2^{+}$modified cancrinites and zeolites $\mathrm{A}$. The $\mathrm{Cu}$ modified solids were not assayed because they were not effective against $E$. coli which is a microorganism much more sensible to antibacterial agents than P. aeruginosa. Results showed an important antibacterial effect using cancrinites modified with $\mathrm{Ag}^{+} .5 \mathrm{mg}$ were enough to reduce to zero the bacteria population while $20 \mathrm{mg}$ were necessary for the rest of modified zeolite to reach the same result. These results showed that this bacterium is more resistant to antibacterial action than E. coli, probable due to its cellular wall which is much thicker than $E$. coli. Contrary to the results obtained with $\mathrm{Ag}^{+}$modified cancrinite, $\mathrm{Ag}^{+}$modified zeolite $\mathrm{A}$ was less effective against $P$. aeruginosa. These results could be attributed to a low liberation of $\mathrm{Ag}^{+}$cation from zeolite $\mathrm{A}$ in comparison with modified $\mathrm{Ag}^{+}$cancrinite. The $\mathrm{Ag}^{+}-\mathrm{Cu}_{2}{ }^{+}$modified zeolites showed a less effectiveness than the modified Ag cancrinite. The presence of $\mathrm{Cu}^{2+}$ cation could be helping in the development of this microorganism due to its importance as an essential microelement.

Table 3. CFU P. aeruginosa determined on Mueller-Hinton culture medium agar plated before and after contact with different amounts of modified cancrinite zeolite or zeolite A.

\begin{tabular}{cccc}
\hline $\begin{array}{c}\text { Modified } \\
\text { zeolite }\end{array}$ & $\begin{array}{c}\text { CFU } \\
\text { initial }\end{array}$ & $\begin{array}{c}\text { Zeolite } \\
\text { (mg) }\end{array}$ & $\begin{array}{c}\mathbf{N}^{\mathbf{0}} \mathbf{U F C} \\
\mathbf{( 2 4} \mathbf{h})\end{array}$ \\
\hline \multirow{2}{*}{ Can-Ag } & 169 & 5.0 & 0 \\
& 169 & 10.0 & 0 \\
& 169 & 20.0 & 0 \\
& 361 & 5.0 & $\mathrm{U}$ \\
$\mathrm{Can}-\mathrm{Ag} / \mathrm{Cu}$ & 153 & 10.0 & 1058 \\
& 164 & 20.0 & 0 \\
& 361 & 5.0 & $\mathrm{U}$ \\
$\mathrm{A}-\mathrm{Ag}$ & 153 & 10.0 & 1216 \\
& 164 & 20.0 & 0 \\
$\mathrm{~A}-\mathrm{Ag} / \mathrm{Cu}$ & 361 & 5.0 & $\mathrm{U}$ \\
& 153 & 10.0 & $\mathrm{U}$ \\
& 164 & 20.0 & 0 \\
\hline
\end{tabular}

Effect of the contact time

$\mathrm{U}$ : uncountable 
Tables 4 and 5 shows the relationship between the CFU and the contact time using E. coli and P.Aeruginosa. $2.5 \mathrm{mg}$ (E. coli) and $20 \mathrm{mg}$ (P. aeruginosa) of modified zeolites were used for these experiments, because they were the minimal amounts of solids that inhibited the bacterial

The contact time was varied between $14 \mathrm{~min}$ and $4320 \mathrm{~min}$ for E. coli while for P. aeruginosa ranged between $10 \mathrm{~min}$ and $1440 \mathrm{~min}$. Table 4 shows an antibacterial effect almost instantaneous against $E$. coli and a contact time of $20 \mathrm{~min}$ is enough to bring down to zero the content of viable cells. These results are interesting, taking into the account that the studied solids showed bactericidal activity not only at short time incubations but at long time treatments (three days: $4320 \mathrm{~min}$ ).

A less value of CFU is observed in Ag-modified zeolites in comparison to those containing $\mathrm{Ag}^{+}$and $\mathrm{Cu}^{2+}$. As we have explained before, $\mathrm{Cu}^{2+}$ can act as an essential microelement in the nutrition of these microorganisms.

Similar results were obtained using P. aeruginosa. In this case, 20 min were also enough to kill the bacterial population, however a larger amount of modified zeolites had to be used $(20 \mathrm{mg})$. Evidently, this bacterium is more resistant to the assayed solids than E. coli as it was explained before.

Table 4. Effect of time in population growing of E. coli.

\begin{tabular}{cccccc}
\hline \multicolumn{5}{c}{ E. coli } \\
\hline $\begin{array}{c}\text { Time } \\
\text { (Min). }\end{array}$ & CFU & Can-Ag/Cu & Can-Ag & A-Ag/Cu & A-Ag \\
initial & CFU & CFU & CFU \\
\hline 0 & 92 & & & 117 & 6 \\
14 & 225 & 107 & 15 & 0 & 0 \\
20 & 250 & 0 & 0 & 0 & 0 \\
40 & 494 & 0 & 0 & 0 & 0 \\
60 & 466 & 0 & 0 & 0 & 0 \\
80 & 722 & 0 & 0 & 0 & 0 \\
1440 & $\mathrm{U}$ & 0 & 0 & 0 & 0 \\
1800 & $\mathrm{U}$ & 0 & 0 & 0 & 0 \\
2480 & $\mathrm{U}$ & 0 & 0 & 0 & 0 \\
4320 & $\mathrm{U}$ & 0 & 0 & & 0 \\
\hline Uncountable & & & & 0
\end{tabular}

Table 5. Effect of time in population growing of $P$. aeruginosa.

\begin{tabular}{cccccc}
\hline \multicolumn{7}{c}{ P. aeruginosa } \\
\hline $\begin{array}{c}\text { Time } \\
(\text { min. })\end{array}$ & $\begin{array}{c}\text { CFU } \\
\text { initial }\end{array}$ & $\begin{array}{c}\text { Can-Ag/Cu } \\
\text { CFU }\end{array}$ & $\begin{array}{c}\text { Can-Ag } \\
\text { CFU }\end{array}$ & $\begin{array}{c}\text { A-Ag/Cu } \\
\text { CFU }\end{array}$ & $\begin{array}{c}\text { A-Ag } \\
\text { CFU }\end{array}$ \\
\hline 0 & 240 & & & & \\
10 & 359 & 6 & 9 & 1 & 3 \\
20 & 369 & 0 & 0 & 0 & 0 \\
65 & 653 & 0 & 0 & 0 & 0 \\
107 & 800 & 0 & 0 & 0 & 0 \\
167 & 820 & 0 & 0 & 0 & 0 \\
1440 & $\mathrm{U}$ & 0 & 0 & 0 & 0 \\
\hline U:uncountable & & & & & \\
\end{tabular}

U:uncountable 


\section{Conclusions}

Sodium-nitrate cancrinite and zeolite A were ion-exchanged using: $\mathrm{Ag}^{+}, \mathrm{Cu}^{2+}$ and $\mathrm{a} \mathrm{Cu}^{2+}-\mathrm{Ag}^{+}$mixture. $\mathrm{Ag}^{+}$ and $\mathrm{Cu}^{2+}$-Ag+zeolites showed bactericidal action against E. coli and P. aeruginosa using low Ag concentrations (5 $\mathrm{mg}$ ) and short contact time (20 $\mathrm{min}) . \mathrm{Ag}^{+}$binds to tissue proteins and brings structural changes in the bacterial cell membranes and cytosolic components leading to cellular distortion and death. $\mathrm{Cu} 2^{+}$zeolites did not show bactericidal activity, and they did not modify the growth of the reference bacterial cultures. $\mathrm{Cu}$ is a bacterial nutrient, required in cellular biochemistry of bacteria and in small quantities it acts as a trace element in the metabolism of the bacteria, the bactericidal effect was not observed under the used experimental conditions.

\section{Acknowledgment}

Authors are grateful to CDCH-UC and FONACIT for its financial support. Many thanks to Prof. Dr. Oscar Valbuena for checking our article.

\section{References}

[1] Barrer R.M and Cole J.F.: "Chemistry of soil minerals. Part VI. Salt entrainment by sodalite and cancrinite during their synthesis". J. Chem. Soc. A., (1970) 1516-1523.

[2] Lindner G., Massa W and Reinen D.J.: "Structure and Properties of Hydrothermally Synthesized Thiosulfate Cancrinite". J. Solid State Chem., Vol. 117, № 2, (1995) 386-391.

[3] Barrer R.M., Cole J.F. and Villiger H.: "Chemistry of soil minerals. Part VII. Synthesis, properties, and crystal structures of salt-filled cancrinites. J. Chem. Soc. A., (1970) 1523-1531.

[4] Linares C. F., Simon C. and Weller M. T.: "Synthesis and characterization of the oxalate cancrinite-type zeolite". Microporous Mesoporous Mater., Vol. 137, № 1-3, (2011) 32-35.

[5] Linares C.F., Sánchez S., Urbina de Navarro C., Rodríguez K. and Goldwasser M.R.: "Study of cancrinitetype zeolites as possible antacid agents". Microporous Mesoporous Mater., Vol. 77, № 2-4, (2005) 215-221.

[6] Linares C.F., Colmenares M., Ocanto F. and Valbuena O.: "Human bile sorption by cancrinite-type zeolites". Mater. Sci. Eng., C, Vol. 29, № 1, (2009) 350-355.

[7] Ocanto F., Linares C.F., Rivero A., Hurtado D., Guanche R. y Cardozo X.: "Un posible uso de las zeolitas cancrinita modificadas como membranas de diálisis para la adsorción de creatinina, urea y p-cresol". Observador del Conocimiento. Vol. 1, № 1, (2013)
$38-45$.

[8] Rivera-Garza M., Olguín M.T., García-Sosa I., Alcántara D. and Rodríguez-Fuentes G. "Silver supported on natural Mexican zeolite as an antibacterial material”. Microporous Mesoporous Mater., Vol. 39, № 3, (2000) 431-444.

[9] Milán Z., de Las Pozas C., Cruz M., Borja R., Sánchez E. Ilangovan K., Espinosa Y. and Luna B., "The removal of bacteria by modified natural zeolites". J. Environ. Sci. Health., Part A, Vol. 36, № 6, (2001) 1073-1087.

[10] Inoue Y., Hoshino M., Takahashi., H., Noguchi., T, Murata T., Kanzaki Y., Hamashima H. and Sasatsu M.: "Bactericidal activity of Ag-zeolite mediated by reactive oxygen species under aerated conditions". J. Inorg. Biochem., Vol. 92, № 1, (2002) 37-42.

[11] Niira R, Yamamoto T., Uchida M. Antibiotic ZeoliteContaining Film. (1996). US Patent No: 5,556,699.

[12] Kaali P., Pérez-Madrigal M. M., Strömberg E., Aune R. E., Czel Gy. and Karlsson S.: "The influence of $\mathrm{Ag}^{+}, \mathrm{Zn}^{2+}$ and $\mathrm{Cu}^{2+}$ exchanged zeolite on antimicrobial and long term in vitro stability of medical grade polyether polyurethane". eXPRESS Polym. Lett., Vol. 5, № 12, (2011) 1028-1040.

[13] Krishnani K.K., Zhang Y., Xiong L., Yan Y., Boopathy. and Mulchandani A.: "Bactericidal and ammonia removal activity of silver ion-exchanged zeolite". Bioresour. Technol., Vol.117, (2012) 86-91.

[14] Zavareh S., Farrokhzad Z. and Darvishi F.: "Modification of zeolite 4A for use as an adsorbent for glyphosate and as an antibacterial agent for water". Ecotoxicol. Environ. Saf., Vol. 155, № 1-8, (2018).

[15] Yan H., Zeng X., Guo L., Lan J., Zhang L. and Cao D.: "Heavy metal ion removal of wastewater by zeoliteimidazolate frameworks". Sep. Purif. Technol. Vol. 194, (2018) 462-469.

[16] Moneim M., Abdelmoneim A., Geies A. and Farghaly S.: "Synthesis, characterization and application of cancrinite in ground water treatment from Wadi ElAssiuti area, Assiut-Egypt". Ass. Univ. Bull. Environ. Res., Vol. 21, № 1, (2018) 23-40).

[17] Peng X., Wang C., Ma B. and Chen Y.: "Removal of $\mathrm{Pb}$ (II) from aqueous solution using a new zeolitetype absorbent: Potassium ore leaching residue". J. Environ. Chem. Eng., Vol. 6, № 6, (2018) 7138-7143.

[18] Ocanto F., Álvarez R., Urbina de Navarro C., Lieb A. and Linares C.F.: "Influence of the alkalinity and $\mathrm{NO}_{3}$ /Cl- anionic composition on the synthesis of the cancrinite-sodalite system". Microporous Mesoporous Mater., Vol. 116, № 1-3, (2008) 318-322. 
[19] Madigan M.T., Martinko J.M., Stahl D.A., Bender S., and Buckley D.: "Brock. Biología de los microorganismos". Pearson Prentice Hall. Madrid. Decimocuarta Edición 2015.

[20] Baerlocher Ch., McCusker| LB. and Olson D.H.: "Atlas of zeolites framework types" Ed. Elsevier, Amsterdam. Sixth Revised Edition 2007.

[21] Treacy M.M. and Higgins J.B.: "Collection of Simulated XRD Powder Patterns for Zeolites" Ed. Elsevier, Amsterdam. Fourth Revised 2001.

[22] Mintova S. and Barrier N.: "Verified Synthesis of Zeolitic Materials" Ed. Elsevier, Amsterdam. Third Revised Edition 2016.

[23] Buhl J-Ch., Stief F., Fechtelkord M., Gesing T.M., Taphorn U. and Taake C.: "Synthesis, X-ray diffraction and MAS NMR characteristics of nitrate cancrinite $\mathrm{Na}_{7.6}\left[\mathrm{AlSiO}_{4}\right]_{6}\left(\mathrm{NO}_{3}\right)_{1.6}\left(\mathrm{H}_{2} \mathrm{O}\right)_{2}{ }_{2}$. J. Alloys Compd., Vol. 305, № 1-2, (2000) 93-102.

[24] Flanigen E., H. Khatami, H. and Syzmansky, H.: "Infrared Structural Studies of Zeolite Frameworks". Adv. Chem. Ser., Vol 101, (1971) 201-229

[25] Barnes MC., Addai-Mensah J. and Gerson AR.: "The mechanism of the sodalite-to-cancrinite phase transformation in synthetic spent Bayer liquor". Microporous Mesoporous Mater., Vol. 31, № 3, (1999) 287-302.
[26] Kwakye-Awuah B., Williams M., Kenward M. and Radecka I.: "Antimicrobial action and efficiency of silver-loaded zeolite X". J. Appl. Microbiol., Vol. 104, (2008)1516-1524.

[27] Feng Q., Wu J., Chen G., Cui F., Kim T. and Kim J.: "A mechanistic study of the antibacterial effect of silver ions on Escherichia coli and Staphylococcus aureus". J. Biomed. Mater. Res., Vol. 52, № 4, (2000) 662-668.

[28] Stewart L.; Thaqi D., Kobe B., McEwan A., Waldron K. and Djoko.: "Handling of nutrient copper in the bacterial envelope”. Metallmics ., Vol. 11, (2019) 50-63.

[29] Nies D.: "The biological chemistry of the transition metal "transportome" of Cupriavidus metallidurans". Metallmics., Vol. 8, (2016) 481-507.

[30] Demirci S., Ustaoğlu Z., Yılmazer G., Sahin F. and Baç N.: "Antimicrobial Properties of Zeolite-X and Zeolite-A Ion-Exchanged with Silver, Copper, and Zinc Against a Broad Range of Microorganisms" Appl. Biochem. Biotechnol., Vol. 172, № 3, (2014) 16521662

[31] Gaceta Oficial Extraordinaria de la República de Venezuela № 5.021 Decreto $\mathrm{N}^{\circ}$ 883. "Normas para la Clasificación y el Control de la Calidad de los Cuerpos de Agua y Vertidos o Efluentes Líquidos" (1995). 


\section{REVISTA TECNICA}

DE LA FACULTAD DE INGENIERIA

UNIVERSIDAD DEL ZULIA

Vol. 42. N³, Septiembre - Diciembre 2019, pp. 104 -151

Esta revista fue editada en formato digital y publicada en Septiembre de 2019, por el Fondo Editorial Serbiluz, Universidad del Zulia. Maracaibo-Venezuela

www.luz.edu.ve

www.serbi.luz.edu.ve

produccioncientifica.luz.edu.ve 